Biogeosciences Discuss., https://doi.org/10.5194/bg-2017-345

Manuscript under review for journal Biogeosciences

Discussion started: 21 August 2017

(c) Author(s) 2017. CC BY 4.0 License.

\title{
A temperature threshold to identify the driving climate forces of the respiratory process in terrestrial ecosystems
}

Zhiyuan Zhang ${ }^{1}$, Renduo Zhang ${ }^{1, *}$, Yang Zhou ${ }^{1,2}$, Alessandro Cescatti ${ }^{3}$, Georg Wohlfahrt ${ }^{4}$, Minmin Sun $^{1}$, Juan Zhu ${ }^{1}$, Vincenzo Magliulo ${ }^{5}$, Feng Tao ${ }^{1}$, and Guanhong Chen ${ }^{1}$

$5{ }^{1}$ School of Environmental Science and Engineering, Guangdong Provincial Key Laboratory of Environmental Pollution Control and Remediation Technology, Sun Yat-sen University, Guangzhou 510275, China

${ }^{2}$ College of Environ mental Science and Engineering, Peking University, Beijing 100871, China

${ }^{3}$ Institute for Environ ment and Sustainability, Climate Risk Management Unit, Eu ropean Co mmission, Joint Research Centre, Is pra 21027, Italy

$10{ }^{4}$ Institute of Ecology, University of Innsbruck, Sternwartestr 15, Innsbruck 6020, Austria

${ }^{5}$ Institute for Mediterranean Agricultural and Forest Systems, National Research Council, Ercolano (Napoli) 80040, Italy

Correspondence to: Renduo Zhang (zhangrd@ mail.sysu.edu.cn)

Abstract. Terrestrial ecosystem respiration $\left(R_{e}\right)$ is the major source of $\mathrm{CO}_{2}$ release and constitutes the second largest carbon flux between the biosphere and atmosphere. Therefore, climate-driven changes of $R_{e}$ may greatly impact on future atmospheric $\mathrm{CO}_{2}$ concentration. The aim of this study was to derive an air temperature threshold for identify ing the driving climate forces of the respiratory process in terrestrial ecosystems within different temperature zones. For this purpose, a global dataset of 647 site-years of ecosystem flux data collected at 152 sites has been examined. Our analysis revealed an ecosystem threshold of mean annual air temperature (MAT) of $11 \pm 2.3^{\circ} \mathrm{C}$. In ecosystems with the MAT below this threshold, the maximum $R_{e}$ rates were primarily dependent on temperature and respiration was mainly a temperature-driven process. On the contrary, in ecosystems with the MAT greater than $11 \pm 2.3^{\circ} \mathrm{C}$, in addition to te mperature, other driving forces, such as water availability and surface heat flux, became significant drivers of the maximum $R_{e}$ rates and respiration was a multifactor-driven process. The information derived from this study highlight the key role of temperature as main controlling factor of the maximum $R_{e}$ rates on a large fraction of the terrestrial biosphere, while other driving forces reduce the maximum $R_{e}$ rates and temperature sensitivity of the respiratory process. These findings are particularly relevant under the current scenario of rapid g lobal warming, given that the potential climate-induced changes in ecosystem respiration may lead to substantial ano malies in the seasonality and magnitude of the terrestrial carbon budget.

\section{Introduction}

Among the greenhouse gases, carbon dioxide $\left(\mathrm{CO}_{2}\right)$ is the one that contributes mostly to the contemporary climate change (IPCC, 2007) and characterized by large global fluxes between the atmosphere, the biosphere, and the anthroposphere. Terrestrial ecosystem respiration $\left(R_{e}\right)$ is the major source of $\mathrm{CO}_{2}$ release and the second largest carbon flux 
Biogeosciences Discuss., https://doi.org/10.5194/bg-2017-345

Manuscript under review for journal Biogeosciences

Discussion started: 21 August 2017

(c) Author(s) 2017. CC BY 4.0 License.

between the biosphere and atmosphere (Raich and Potter, 1995). Therefore, climate-induced change in $R_{e}$ may profoundly impact the global carbon cycle (Yvon-Durocher et al., 2012).

The total ecosystem respiration is composed of heterotrophic respiration and autotrophic respiration, which may response to different driving forces, including biotic and abiotic factors (Falge et al., 2002). However, among the major ecological factors, temperature is prominent to determine the natural distribution of plants and to regulate activities of microbial communities (Lipson et al., 2000). It has been shown that $R_{e}$ rates increase exponentially with temperature (Enquist et al., 2003; Gillooly et al., 2001). However, the temperature dependence of respiration can be modified by many variables at the ecosystem level (Allen et al., 2005; Luo, 2007; Mahecha et al., 2010). According to the metabolic theory of ecology, the temperature dependence of $R_{e}$ has been quantified by a constant activation energy $(E=0.60 \mathrm{eV})(\mathrm{Brown}$ et al.,

10 2004; Enquist et al., 2003; Gillooly et al., 2001). By contrast, some other authors have shown varied average $E$ values of $R_{e}$ with ecosystem types and climate zones (Price and Sowers, 2004; Song et al., 2014). Similarly, inconsistent results of temperature sensitivity of $R_{e}$ quantified by $Q_{10}$, which is the proportional increase in respiration per $10^{\circ} \mathrm{C}$ rise, have been reported in the literature. A constant $Q_{10}$ value of $R_{e}$ has been utilized in several ecosystem models (Xu and Qi, 2001). Curiel Yuste et al. (2004) found that the $Q_{10}$ values of soil respiration were similar among diffe rent vegetation types at short-

15 term time scale. Mahecha et al. (2010) showed that $Q_{10}$ values of $R_{e}$ were independent of temperature and converged on aconstant value across biomes. On the contrary, $Q_{10}$ values have been shown to change with different ecosystem types or even different vegetation types within an ecosystem(Lavigne et al., 2003; Melillo et al., 2002; Song et al., 2014; Zheng et al., 2009).

Besides temperature, other environ mental factors can affect $R_{e}$ values (Han et al., 2007; Schaefer et al., 2009; W iseman 20 and Seiler, 2004). So me micro meteorological factors can affect the as similatory process of plants and therefore the substrate quantitity and quality for respiration (Högberg et al., 2001; Rogers and Humphries, 2000; Sage and Kubien, 2007). In particular water availability (e.g., soil water content and precipitation) is often reported as a key co-acting or controlling factor of $R_{e}$ in different temperature regimes (Conant et al., 2000; Li et al., 2006). The apparent inconsistency in the literature about these processes are often due to the combined effect of different driving forces on the respiratory process that may u ltimately lead to different apparent temperature sensitivities of $R_{e}$ rates.

The concept of ecological threshold has been widely recognized as an important paradigm to assess the effect of environmental limiting factors on biological processes (Holling, 1973; Larsen and Alp, 2015). As a turning point, the ecological threshold divides the ecosystems into two groups, between which the driving forces of ecological process are different (Andersen et al., 2009; Scheffer and Carpenter, 2003). The ecological threshold is also linked to alternatively

30 stable states in the structure and function of ecosystems. Therefore, the alternatively stable states represent different combinations of ecosystem components (e.g., assemblage of species, productivity) and environmental conditions that may stably persist at certain spatial and te mporal scales (Suding et al., 2004).

According to the review of $R_{e}$ and the concept of ecological threshold, here we hypothesize that there is a temperature threshold that can be utilized to identify the driving climate forces of the respiratory process in terrestrial ecosystems within 
Biogeosciences Discuss., https://doi.org/10.5194/bg-2017-345

Manuscript under review for journal Biogeosciences

Discussion started: 21 August 2017

(c) Author(s) 2017. CC BY 4.0 License.

different temperature zones. Therefore, the objectives of this study were to investigate the effects of air temperature and other micrometeorological factors, including greenhouse gases (e.g., atmospheric $\mathrm{CO}_{2}$ concentration and atmospheric $\mathrm{H}_{2} \mathrm{O}$ content), heat flux (e.g., soil heat flux, sensible heat flux, and latent heat flux), and water availability (e.g., precipitation, relative humidity, and soil water content), on $R_{e}$ at different latitude regions and to quantify the temperature threshold for

5 respiratory process in different terrestrial ecosystems. This study was carried out using a global dataset covering broad environmental grad ients.

\section{Materials and Methods}

\subsection{Data}

In total, 647 site-years data were collected at 152 eddy fluxsites globally. Basic information of the database, including

10 site ID, latitude, longitude, PFT, climate class, year of data collection, and reference of each data set, is listed Table S1 (Supplement). Annual ecosystem respiration rates were estimated from the mean NEE values measured during nighttime. At least five data points for each day and at least 255 measurements in each site were required for the estimation (Mahecha et al., 2010). Mean annual air temperatures (MAT) and other mean annual values of selected micrometeorological factors (i.e., greenhouse gases, heat flux, and water availability), including atmospheric $\mathrm{CO}_{2}$ concentration (denoted by $\mathrm{CO}_{2}$ ), 15 atmospheric $\mathrm{H}_{2} \mathrm{O}$ content $\left(\mathrm{H}_{2} \mathrm{O}\right)$, soil heat flux $(\mathrm{G})$, sensible heat flux $(\mathrm{H})$, latent heat flux (LE), precipitation (P), relative humidity $(\mathrm{RH})$, and soil water content (SWC), over the same periods for $\mathrm{CO}_{2}$ flux measurements were used as the corresponding data for analysis.

\subsection{Data analysis}

If temperature is the primary determinant of $R_{e}$ rates (i.e., temperature-driven pattern), the maximum realizable $R_{e}$ rate 20 (i.e., the upper bound of $R_{e}$ rate) should increase with MAT (Kätterer et al., 1998; Rustad et al., 2001). If other micrometeoro logical factors in addition to temperature control $R_{e}$ rates, the change of maximum realizable $R_{e}$ rate with MAT is expected to be different from that of the temperature-driven pattern (Flanagan and Johnson, 2005; Xu et al., 2004). Based on the hypothesis above, the quantile regression was applied to evaluate relationships between $R_{e}$ rate and MAT, and other micrometeorological factors (i.e., $\mathrm{CO}_{2}, \mathrm{H}_{2} \mathrm{O}, \mathrm{G}, \mathrm{H}, \mathrm{LE}, \mathrm{P}, \mathrm{RH}$, and SWC). Following the procedure of Cade and Noon

25 (2003), we applied the quantile linear regression at the quantile levels of $\tau \in(0.90,0.95,0.99)$ to evaluate relationships of the maximu m realizable $R_{e}$ rates vs. temperature and other micrometeorological factors. For a tested factor, if quantile slopes at all $\tau$ levels are significantly different from zero, the maximum realizable $R_{e}$ rates are significantly corre lated to the factor. If the correlation (i.e., positive or negative) trends between the maximum realizable $R_{e}$ rates and a factor at the three linear quantiles are not consistent, the quantile linear regression should be further tested at more quantiles. Many changes in 30 ecological processes occur with gradual transitions (Sankaran et al., 2005). Thus, we used a bent-cable model as a more 
Biogeosciences Discuss., https://doi.org/10.5194/bg-2017-345

Manuscript under review for journal Biogeosciences

Discussion started: 21 August 2017

(c) Author(s) 2017. CC BY 4.0 License.

flexible model to describe the gradualchanges from one ecological state to another to form a piecewise linear model (Chiu et al., 2006). The model was implemented in the 'quantreg' library in the statistical package R (http://www.r-project.org).

In addition to analyzing patterns of the maximum $R_{e}$ rates, a regression tree analys is was conducted to determine the effects of temperature and other mic rometeorological factors on the mean realizable $R_{e}$ rates. After tree construction, cross -

validation procedures were used to refine the trees to better represent relationships among the variables (De'ath and Fabricius, 2000). The regression tree analysis was implemented in 'rpart' library in the statistical package R. Further details on the methodology are provided in the Supplement.

\section{Results}

\subsection{Relationship between the maximum realizable $R_{e}$ rate and MAT}

Using the quantile piecewise linear regression at $\tau=0.99$, we evaluated the upper bound of $R_{e}$ rates (i.e., the maximum realizable $R_{e}$ rates) changing with MAT. As shown in Fig. 1, a threshold of MAT was identified as $11 \pm 2.3^{\circ} \mathrm{C}$. Within a MAT range below the threshold, the relationship between the maximum realizable $R_{e}$ rate and MAT was characterized with a linear equation $R_{e}=0.19(\mathrm{MAT})+2.49$. In ecosystems with MAT $>11 \pm 2.3{ }^{\circ} \mathrm{C}$, the relationship between the maximum realizable $R_{e}$ rates and MAT was characterized with a linear equation $R_{e}=0.07(\mathrm{MAT})+3.81$.

According to the MAT threshold, terrestrial ecosystems across the globe can be divided into two regions (Fig. 2). Basically, terrestrial ecosystems with MAT $\leqslant$ the threshold are within the high-latitude regions and terrestrial ecosystems with MAT > the threshold are with in the lower-latitude regions.

\subsection{Relationships between the maximum realizable $\boldsymbol{R}_{e}$ rate and other micrometeorological factors}

Based on the temperature threshold, the data was divided into two groups: one for sites with MAT $\leqslant$ the threshold and another for sites with MAT $>$ the threshold. The quantile linear regression at $\tau \in(0.90,0.95,0.99)$ was applied to evaluate the relationships between the maximum realizable $R_{e}$ rates and MAT as well as the micrometeorological factors, or the driving forces for the maximum realizable Re rates. In the ecosystems with MAT $\leqslant 11 \pm 2.3^{\circ} \mathrm{C}$, the maximum realized $R_{e}$ rates increased with MAT (Fig. 3a), but decreased with $\mathrm{H}$ (Fig. 3b). However, the maximum realized $R_{e}$ rates were not significantly correlated with other micrometeorological factors of $\mathrm{CO}_{2}, \mathrm{G}_{1} \mathrm{H}_{2} \mathrm{O}, \mathrm{LE}, \mathrm{P}, \mathrm{RH}$, and SWC (Table 1, Fig. 3c-j).

In sites with MAT $>11 \pm 2.3^{\circ} \mathrm{C}$ (i.e., the lower-latitude sites), besides temperature, some micrometeorological factors also profoundly affected the maximum realizable $R_{e}$ rate. As shown in Fig. 4 and Table 2 , the maximum realizable $R_{e}$ rates were positively correlated to MAT, H2O, and SWC, and negatively correlated to $\mathrm{H}$ and LE. For the data of maximum realizable $R_{e}$ rates vs. LE, the quantile slopes at $90 t h, 95 t h$ and $99 t h$ percentiles we re significantly different from zero (Table 2), but did not show consistently positive or negative relationships. Therefore, further quantile linear regressions at $\tau$ levels 
Biogeosciences Discuss., https://doi.org/10.5194/bg-2017-345

Manuscript under review for journal Biogeosciences

Discussion started: 21 August 2017

(c) Author(s) 2017. CC BY 4.0 License.

of $10 t h-80 t h$ were conducted, which confirmed the negative relationship between the maximum realizable $R_{e}$ rates and LE (Fig. 4f).

Since temperature is a function of sensible heat (Lindau, 2001), the corre lation between the maximum realizable $R_{e}$ rate and $\mathrm{H}$ indeed refers to the relationship of $R_{e}$ rate and temperature.

\subsection{Effects of environmental factors on the mean realizable $R_{e}$ rate}

A regression tree analysis of mean $R_{e}$ rates for a restricted subset of sites showed that MAT was the principal driving force of respiratory process of terrestrial ecosystems (Fig. 5). In sites with MAT $<2.96{ }^{\circ} \mathrm{C}$, the mean $R_{e}$ rates were typically low and other micrometeorological factors rarely regulated the $R_{e}$ rates. In sites with $\mathrm{MAT}>2.96{ }^{\circ} \mathrm{C}$, $\mathrm{RH}$ became a controlling factor to reduce $R_{e}$ rates below the MAT-controlled upper bound. At the next level in the tree, LE became a relevant factor in regulating the mean $R_{e}$ rates. Within a certain $\mathrm{RH}$ value, a lower LE resulted in a higher $R_{e}$ rate. The sequence in Fig. 5 indicated that besides temperature, water availability and heat flux were the key factors to regulate the respiratory process of terrestrial ecosystems.

\section{Discussion}

\subsection{Patterns of $R_{e}$ response to temper ature}

Physiological processes of ecosystems are dependent on the enzyme kinetics, which are largely controlled by temperature (Brown et al., 2004). Higher temperatures generally increase biochemical reaction rates, metabolic rates, and rates of other biological activities (Brown et al., 2004). Although $R_{e}$ rates increased with temperature across all sites in this study, $R_{e}$ rates in different regimes responded to temperature differently. In the high-latitude region with low temperatures, root respiration of plants and microbial metabolis $\mathrm{m}$ are primary controlled by temperature (Bond-Lamberty et al., 2004; Lavigne et al., 2003). The decomposition rates of soil organic matter are relatively low in these regions so that substrate is abundant (Davidson and Janssens, 2006). According to Michaelis-Menten kinetics (Michaelis and Menten, 1913), if substrate is abundant and temperature does not exceed the optimum temperature, the reaction rate is determined by temperature (Atkin and Tjoelker, 2003). This state of $R_{e}$ rates responding to temperature indicates that the maximum realizable $R_{e}$ rates are primarily controlled by temperature.

In lower-latitude regions with higher temperatures, besides temperature, other micrometeorological factors also affect Re rates (Rustad et al., 2000). In these regions, the decomposition rates of soil organic matter are relatively high (Davids on and Janssens, 2006), which results in low substrate availability. Water availability may also limit the substrate accessibility of microbes. Therefore, besides temperature, substrate quality, availability, and accessibility beco me relevant for en zy me catalysed reaction rates (Berry and Raison, 1981; Davidson et al., 2006). This state of $R_{e}$ rates responding to temperature implies that the respiratory process of terrestrial ecosystem is in a mu lti-factor-driven pattern. 
Biogeosciences Discuss., https://doi.org/10.5194/bg-2017-345

Manuscript under review for journal Biogeosciences

Discussion started: 21 August 2017

(c) Author(s) 2017. CC BY 4.0 License.

At the ecosystem level, temperature changes may be associated with changes in the water balance via evapotranspiration and altered precipitation regimes (IPCC, 2007; Swann et al., 2016). Temperature increases enhance evapotranspiration and reduce water availability.On the other hand, the physiolog ical response of plants to warming climate with the stomatal conductance reduction may decrease water losses from the land surface (Swann et al., 2016). These two

5 opposite processes make the respiratory process of ecosystem more complicated in the high te mperature regions (Balogh et al., 2015; Kool et al., 2014). The temperature effect on microbial communities may also alter ecosystem carbon and nutrient balances (Högberg et al., 2007; Karhu et al., 2014). Evidence shows that microbial communities and activities are different at the two end members of the temperature range $\left(7-14^{\circ} \mathrm{C}\right.$ ) (Allison and Treseder, 2008; Crowther and Bradford, 2013; Karhu et al., 2014; Nie et al., 2013).

\subsection{Relationships between $R_{e}$ and other micrometeor ological factors}

Water availability influences autotrophic respiration by controlling plant growth and development (i.e., production of substrate), photosynthes is and carbon allocation patters (i.e., distribution of substrate) (Flanagan and Johnson, 2005). Wat er availability can also affect heterotrophic respiration through controlling microbial growth and development, and the supply and quality of respiratory substrate provided by plants (Raich and Tufekciogul, 2000). Therefore, many studies have shown

15 that soil mo isture can influence soil respiration (Cu riel Yuste et al., 2003; Janssens and Pilegaard, 2003; Lavigne et al., 2004; Reichstein et al., 2002). The thin soil water films in a dry condition should obstruct enzyme diffusion and reduce substrate availability, while oxygen deficit in saturated soils creates anaerobic conditions. There is an optimal soil water content for respiration (Davidson and Janssens, 2006). Generally, within a certain range of soil moisture content, soil respiration increases with water content (Flanagan and Johnson, 2005; Reichstein et al., 2003). In semi-arid and arid regions, soil

20 moisture is the second most important abiotic variable for soil respiration (Qi and Xu, 2001). Even in Mediterranean ecosystems, water availability is the main environmental constraint for plant growth and reproduction (Pausas, 1999) and may become an even more limiting resource under the increasing aridity predicted for this region by most climate models (Kéfi et al., 2007).

The effect of precipitation on soil respiration extends beyond its direct effect via soil mo isture (Reichstein et al., 2003).

25 Because of highly spatial and temporal variability of rainfall (Bowling et al., 2002; Curiel Yuste et al., 2003; Huxman et al., 2004; Xu et al., 2004), we did not observe any relationship between the maximu m realizable $R_{e}$ rate and precipitation.

Sensible and latent heat fluxes (H and LE) are non-radiative pathways for energy transfer from the Earth surface to the atmosphere. Both $\mathrm{H}$ and LE are important components of the Earth's surface energy budget (Rebmann et al., 2012). More available energy of ecosystem partitioning to $\mathrm{H}$ leads to high vapour pressure deficit, which is a major impact factor on the rate of net photosynthesis (Lambers et al., 1998). It has been shown that the vapour pressure deficit negatively affects $R_{e}$ rates (Ekblad et al., 2005; Seneweera et al., 1998). Thus $R_{e}$ rates are negatively correlated to H. The evapotranspiration is a function of LE (Gentine et al., 2007), and increased evapotranspiration will reduce water availability of ecosystems. Therefore, the $R_{e}$ rates are negatively correlated with LE. 
Biogeosciences Discuss., https://doi.org/10.5194/bg-2017-345

Manuscript under review for journal Biogeosciences

Discussion started: 21 August 2017

(c) Author(s) 2017. CC BY 4.0 License.

As one of greenhouse gases (Rodhe, 1990), atmospheric $\mathrm{H}_{2} \mathrm{O}$ content (water vapour) increase may accelerate respiratory process of terrestrial ecosystem (Wang et al., 2016). In addition, elevated $\mathrm{H}_{2} \mathrm{O}$ reduces the vapour pressure deficit, resulting in higher $R_{e}$ rates(Ekblad et al., 2005; Seneweera et al., 1998). There fore, $R_{e}$ rates are positively correlated to $\mathrm{H}_{2} \mathrm{O}$.

\section{$5 \quad 4.3$ Temperature sensitivities under different temperature zones}

Temperature is the primary factor in regulating respiratory process of terrestrial ecosystem. Since the regression tree in Fig. 4 split data based on variance of the predictor variables, different temperature thresholds were obtained in the terminal nodes. Several authors pointed out that $Q_{10}$ values of $R_{e}$ rates decrease with temperature (Atkin and Tjoelker, 2003; Hamdi et al., 2013; Schipper et al., 2014). Similarly, as indicated in Fig. 1, the temperature dependence of $R_{e}$ at low temperatures

10 (or in high-latitude regions) is stronger than that at high temperatures (or in lower-latitude regions). In other words, the temperature sensitivity of $R_{e}$ at low temperatures is higher than that at high temperatures. Biochemical reactions require appropriate activation energies under different initial ambient temperatures, according to the Arrhenius equation (Blankenship, 2013; Laidler, 1996). More activation energy is required to complete the reaction at a lower temperature (Cai et al., 2014). $R_{e}$ in response to a temperature change may be interpreted as respiration acclimation to temperature (Atkin and

15 Tjoelker, 2003). Temperature acclimation indicates that with increasing global te mperature, plants and microorganis ms may generate reversible changes in a way that can optimize their functioning under warmer environment, a process also described as temperature adaptation (Saxe et al., 2001). Such adaptation mechanism may result in compensation of ecological processes (e.g., $R_{e}$ ) in response to a change in temperature and subsequently reduce the temperature sensitivity of ecological processes (Luo et al., 2001; Tjoelker et al., 2008). Using field measurement data, Reich et al. (2016) demonstrated strong acclimation of plant respiration to seasonal temperature increase. The acclimation mechanism reduces plant respiration rate greatly and decreases $Q_{10}$ values (Reich et al., 2016).

\section{Conclusions}

The results from this global scale analysis indicate that temperature is the main driving force of the maximum realizable $R_{e}$ rates in almost all terrestrial ecosystems, while other micrometeorological factors (e.g., water availability and heat flux) reduce the maximum realizable $R_{e}$ rates in higher temperature regions. A temperature threshold was derived to identify the driving forces of the respiratory process in terrestrial ecosystems under different climate regions. These findings highlight the key importance of climate drivers on the terrestrial carbon balance and may have important implications for the benchmarking and refinement of biogeochemical land models (Flanagan and Johnson, 2005; Frank et al., 2010; Reynolds et al., 2015). Better understanding of the driving forces of ecosystem respiration should enhance the capacity to accurately estimate ecosystem carbon fluxes and predict future climate trajectories. 
Biogeosciences Discuss., https://doi.org/10.5194/bg-2017-345

Manuscript under review for journal Biogeosciences

Discussion started: 21 August 2017

(c) Author(s) 2017. CC BY 4.0 License.

\section{Data availability}

The measured $\mathrm{CO}_{2}$ fluxes and meteorological data are obtained from the La Thuile Dataset, which are freely available at the FLUXNET community (http://fluxnet.fluxdata.org/data/la-thuile-dataset/). The mean annual temperature data are gathered from the MODIS subset product, and they are freely available at the MODIS subset website 5 (https://gmao.gsfc.nasa.gov/reanalysis/MERRA/).

\section{Author Contributions}

This study was conceived and designed by Z.Z., R.Z. Calculations and analysis was performed by Y.Z. The data were collected by J.Z. Z.Z., R.Z., A.C., G.W. and V.M. wrote the paper, with contributions and comments from all other authors.

\section{Acknowledg ments}

This study was supported by grants from the Chinese National Natural Science Foundation (Nos. 41471181 and 51179212). We also acknowledge all the principal investigators and data providers for sharing their flux data. The following networks provided flux data: FLUXNET, A meriFlux, AsiaFlux, ORNL DAAC, FFPRI Flu xnet (supported by Forestry and Forest Products Research Institute), European Fluxes Database Cluster. This work used eddy covariance data mostly acquired by the FLUXNET community, which is in particular provided by the following networks: A meriFlux [U.S. Department of Energy, Biological and Environ mental Research, Terrestrial Carbon Program (DE - FG02 - 04ER63917 and DE - FG02 - 04ER63911)], AfriFlux, AsiaFlux, CarboAfrica, CarboEuropeIP, CarboItaly, CarboMont, ChinaFlux, Flu xnet - Canada (supported by CFCAS, NSERC, BIOCAP, Environment Canada, and NRCan), Green Grass, KoFlux, LBA, NECC, OzFlux, TCOS - Siberia, USCCC. We acknowledge the financial support to the eddy covariance data harmonization provided by CarboEuropeIP, FAO - GTOS - TCO, iLEAPS, Max Planck Institute for Biogeochemistry,

20 National Science Foundation, University of Tuscia, Université Laval and Environment Canada and US Department of Energy and the database development and technical support from Berkeley Water Center, Lawrence Berkeley National Laboratory, Microsoft Research eScience, Oak Ridge National Laboratory, University of Californ ia-Berkeley, University of Virginia.

\section{References}

Allen, A. P., Gillooly, J. F., and Brown, J. H.: Linking the global carbon cycle to individual metabolis m, Funct. Ecol., 19, 202-213, 2005.

Allison, S. D. and Treseder, K. K.: Warming and drying suppress microbial activity and carbon cycling in boreal forest soils, 
Biogeosciences Discuss., https://doi.org/10.5194/bg-2017-345

Manuscript under review for journal Biogeosciences

Discussion started: 21 August 2017

(c) Author(s) 2017. CC BY 4.0 License.

Global Change Biol., 14, 2898-2909, 2008.

Andersen, T., Carstensen, J., Hernández-García, E., and Duarte, C. M.: Ecological thresholds and regime shifts: approaches to identification, Trends Ecol. Evol., 24, 49-57, 2009.

Atkin, O. K. and Tjoelker, M. G.: Thermal acclimation and the dynamic response of plant respiration to temperature, Trends in Plant Science, 8, 343-351, 2003.

Balogh, J., Fóti, S., Pintér, K., Burri, S., Eugster, W., Papp, M., and Nagy, Z.: Soil CO 2 efflux and production rates as influenced by evapotranspiration in a dry grassland, Plant Soil, 388, 157-173, 2015.

Berry, J. A. and Raison, J. K.: Responses of Macrophytes to Temperature. In: Physiological Plant Ecology I: Responses to the Physical Environment, Lange, O. L., Nobel, P. S., Osmond, C. B., and Ziegler, H. (Eds.), Springer Berlin Heidelberg, Berlin, Heidelberg, 277-338 pp., 1981.

Blankenship, R. E.: Molecular mechanisms of photosynthesis, John Wiley \& Sons, 2013.

Bond-Lamberty, B., Wang, C., and Gower, S. T.: Contribution of root respiration to soil surface $\mathrm{CO}_{2}$ flux in a boreal black spruce chronosequence, Tree Physiol., 24, 1387-1395, 2004.

Bowling, D. R., McDowell, N. G., Bond, B. J., Law, B. E., and Ehleringer, J. R.: ${ }^{13}$ C content of ecosystem respiration is lin ked to precipitation and vapor pressure deficit, Oecologia, 131, 113-124, 2002.

Brown, J. H., Gillooly, J. F., Allen, A. P., Savage, V. M., and West, G. B.: To ward a metabolic theory of ecology, Ecology, 85, 1771-1789, 2004.

Cade, B. S. and Noon, B. R.: A gentle introduction to quantile regression for ecologists, Front. Ecol. Environ., 1, 412-420, 2003.

20 Cai, J., Wu, W., and Liu, R.: An overview of distributed activation energy model and its application in the pyrolysis of lignocellulosic bio mass, Renew. Sust. Energ. Rev., 36, 236-246, 2014.

Chiu, G., Lockhart, R., and Routledge, R.: Bent-Cable regression theory and applications, J. A m. Stat. Assoc., 101, 542-553, 2006.

Conant, R. T., Klopatek, J. M., and Klopatek, C. C.: Environmental factors controlling soil respiration in three semiarid ecosystems, Soil Sci. Soc. Am. J., 64, 383-390, 2000.

Crowther, T. W. and Bradford, M. A.: Thermal acclimation in widespread heterotrophic soil microbes, Ecol. Lett., 16, 469477, 2013.

Curiel Yuste, J., Janssens, I. A., Carrara, A., and Ceulemans, R.: Annual $Q_{10}$ of soil respiration reflects plant phenological patterns as well as te mperature sensitivity, Global Change Biol., 10, 161-169, 2004. 
Biogeosciences Discuss., https://doi.org/10.5194/bg-2017-345

Manuscript under review for journal Biogeosciences

Discussion started: 21 August 2017

(c) Author(s) 2017. CC BY 4.0 License.

Curiel Yuste, J., Janssens, I. A., Carrara, A., Meiresonne, L., and Ceulemans, R.: Interactive effects of temperature and precipitation on soil respiration in a temperate maritime pine forest, Tree Physiol., 23, 1263-1270, 2003.

Davidson, E. A. and Janssens, I. A.: Temperature sensitivity of soil carbon decomposition and feedbacks to climate change, Nature, 440, 165-173, 2006.

5 Davidson, E. A., Janssens, I. A., and Luo, Y.: On the variability of respiration in terrestrial ec osystems: moving beyond $Q_{10}$, Global Change Biol., 12, 154-164, 2006.

De'ath, G. and Fabricius, K. E.: Classification and regression tree: A powerful yet simple technique for ecological data analysis, Ecology, 81, 3178-3192, 2000.

Ekblad, A., Boström, B., Holm, A., and Comstedt, D.: Forest soil respiration rate and $\delta^{13} \mathrm{C}$ is regulated by recent above ground weather conditions, Oecologia, 143, 136-142, 2005.

Enquist, B. J., Economo, E. P., Huxman, T. E., Allen, A. P., Ignace, D. D., and Gillooly, J. F.: Scaling metabolism from organisms to ecosystems, Nature, 423, 639-642, 2003.

Falge, E., Baldocchi, D., Tenhunen, J., Aubinet, M., Bakwin, P., Berbig ier, P., Bernhofer, C., Burba, G., Clement, R., Davis, K. J., Elbers, J. A., Goldstein, A. H., Grelle, A., Granier, A., Guðmundsson, J., Hollinger, D., Kowalski, A. S., Katul, G., Law, B. E., Malhi, Y., Meyers, T., Monson, R. K., Munger, J. W., Oechel, W., Paw U, K. T., Pilegaard, K., Rannik, Ü., Rebmann, C., Suyker, A., Valentini, R., Wilson, K., and Wofsy, S.: Season ality of ecosystem respiration and gross primary production as derived from FLUXNET measurements, Agr. Forest Meteorol., 113, 53-74, 2002.

Flanagan, L. B. and Johnson, B. G.: Interacting effects of temperature, soil moisture and plant biomass production on ecosystem respiration in a northern temperate grassland, Agr. Forest Meteorol., 130, 237-253, 2005.

Frank, D. C., Esper, J., Raible, C. C., Buntgen, U., Trouet, V., Stocker, B., and Joos, F.: Ensemble reconstruction constrain ts on the global carbon cycle sensitivity to climate, Nature, 463, 527-530, 2010.

Gentine, P., Entekhabi, D., Chehbouni, A., Boulet, G., and Duchemin, B.: Analysis of evaporative fraction diurnal behaviour, Agr. Forest Meteorol., 143, 13-29, 2007.

Gillooly, J. F., Brown, J. H., West, G. B., Savage, V. M., and Charnov, E. L.: Effects of size and temperature on metabolic rate, Science, 293, 2248-2251, 2001.

Hamdi, S., Moyano, F., Sall, S., Bernoux, M., and Chevallier, T.: Synthesis analysis of the temperature sensitivity of soil respiration from laboratory studies in relation to incubation methods and soil conditions, Soil Biol. Biochem., 58, 115-126, 2013.

Han, G., Zhou, G., Xu, Z., Yang, Y., Liu, J., and Shi, K.: Biotic and abiotic factors controlling the spatial and temporal variation of soil respiration in an agricultural ecosystem, Soil Biol. Biochem., 39, 418-425, 2007. 
Biogeosciences Discuss., https://doi.org/10.5194/bg-2017-345

Manuscript under review for journal Biogeosciences

Discussion started: 21 August 2017

(c) Author(s) 2017. CC BY 4.0 License.

Högberg, M. N., Högberg, P., and Myrold, D. D.: Is microbial community composition in boreal forest soils determined by pH, C-to-N ratio, the trees, or all three?, Oecologia, 150, 590-601, 2007.

Högberg, P., Nordgren, A., Buch mann, N., Taylor, A. F. S., Ekblad, A., Högberg, M. N., Nyberg, G., Ottosson-Lofvenius, M., and Read, D. J.: Large-scale forest girdling shows that current photosynthes is drives soil respiration, Nature, 411, 789-792, 2001.

Holling, C. S.: Resilience and stability of ecological systems, Annu. Rev. Ecol. Evol. S., 4, 1-23, 1973.

Huxman, T. E., Snyder, K. A., Tissue, D., Leffler, A. J., Ogle, K., Pockman, W. T., Sandquist, D. R., Potts, D. L., and Schwinning, S.: Precipitation pulses and carbon fluxes in semiarid and arid ecosystems, Oecologia, 141, 254-268, 2004.

10 IPCC: Contribution of Working Group I to the Fourth Assess ment Report of the Intergovernmental Panel on Climate Change. In: Climate Change 2007: The Physical Science Basis, Cambridge University Press, Cambridge, UK and New York, NY., 2007.

Janssens, I. A. and Pilegaard, K. I. M.: Large seasonal changes in $Q_{10}$ of soil respiration in a beech forest, Global Change Biol., 9, 911-918, 2003.

15 Karhu, K., Auffret, M. D., Dungait, J. A. J., Hopkins, D. W., Prosser, J. I., Singh, B. K., Subke, J. -A., Wookey, P. A., Agren, G. I., Sebastia, M.-T., Gouriveau, F., Bergkvist, G., Meir, P., Nottingham, A. T., Salinas, N., and Hartley, I. P.: Temperature sensitivity of soil respiration rates enhanced by microbial community response, Nature, 513, 81 -84, 2014.

Kätterer, T., Reichstein, M., Andrén, O., and Lomander, A.: Temperature dependence of organic matter decomposition: a critical review using literature data analyzed with different models, Biol. Fert. Soils, 27, 258-262, 1998.

Kéfi, S., Rietkerk, M., Alados, C. L., Pueyo, Y., Papanastasis, V. P., ElAich, A., and de Ruiter, P. C.: Spatial vegetation patterns and imminent desertification in Mediterranean arid ecosystems, Nature, 449, 213-217, 2007.

Kool, D., Agam, N., Lazarovitch, N., Heitman, J. L., Sauer, T. J., and Ben-Gal, A.: A review of approaches for evapotranspiration partitioning, Agr. Forest Meteorol., 184, 56-70, 2014.

Laidler, K. J.: A g lossary of terms used in chemical kinetics, including reaction dynamics (IUPAC Recommendations 1996), Pure Appl. Chem., 68, 149-192, 1996.

Lambers, H., Chapin, F. S., and Pons, T. L.: Photosynthesis, Respiration, and Long-Distance Transport. In: Plant Physiological Ecology, Lambers, H., Chapin, F. S., and Pons, T. L. (Eds.), Springer New York, New York, NY, 10153 pp., 1998.

30 Larsen, S. and Alp, M.: Ecological thresholds and riparian wetlands: an overview for environ mental managers, Limnology, 
Biogeosciences Discuss., https://doi.org/10.5194/bg-2017-345

Manuscript under review for journal Biogeosciences

Discussion started: 21 August 2017

(C) Author(s) 2017. CC BY 4.0 License.

16, 1-9, 2015.

Lavigne, M. B., Boutin, R., Foster, R. J., Goodine, G., Bernier, P. Y., and Robitaille, G.: Soil respiration responses to temperature are controlled more by roots than by decomposition in balsam fir ecosystems, Can. J. Forest Res., 33, 1744-1753, 2003.

5 Lavigne, M. B., Foster, R. J., and Goodine, G.: Seasonal and annual changes in soil respiration in re lation to soil te mperature, water potential and trenching, Tree Physiol., 24, 415-424, 2004.

Li, Y., Xu, M., and Zou, X.: Heterotrophic soil respiration in relation to environmental factors and microbial biomass in two wet tropical forests, Plant Soil, 281, 193-201, 2006.

Lindau, R.: Sensible Heat Flux. In: Climate Atlas of the Atlantic Ocean: Derived from the Comprehensive Ocean Atmosphere Data Set (COADS), Lindau, R. (Ed.), Springer Berlin Heidelberg, Berlin, Heidelberg, 383-397 pp.,2001.

Lipson, D. A., Schmidt, S. K., and Monson, R. K.: Carbon availability and temperature control the post-snowmelt decline in alpine soil microbial bio mas s, Soil Biol. Biochem., 32, 441-448, 2000.

Luo, Y., Wan, S., Hui, D., and Wallace, L. L.: Acclimatization of soil respiration to warming in a tall grass prairie, Nature, $413,622-625,2001$.

Luo, Y.: Terrestrial carbon-cycle feedback to climate warming, Annu. Rev. Ecol. Evol. S., 38, 683-712, 2007.

Mahecha, M. D., Reichstein, M., Carvalhais, N., Lasslop, G., Lange, H., Seneviratne, S. I., Vargas, R., A mmann, C., Arain, M. A., Cescatti, A., Janssens, I. A., Migliavacca, M., Montagnani, L., and Richardson, A. D.: Global convergence in the temperature sensitivity of respiration at ecosystem level, Science, 329, 838-840, 2010.

Melillo, J. M., Steudler, P. A., Aber, J. D., Newkirk, K., Lux, H., Bowles, F. P., Catricala, C., Magill, A., Ahrens, T., and Morris seau, S.: Soil warming and carbon-cycle feedbacks to the climate system, Science, 298, $2173,2002$.

Michaelis, L. and Menten, M. L.: Die kinetik der invertin wirkung, Biochem. Z., 49, 334-336, 1913.

Nie, M., Pendall, E., Bell, C., Gasch, C. K., Raut, S., Tamang, S., and Wallenstein, M. D.: Positive climate feedbacks of soil microbial co mmun ities in a semi-arid grassland, Ecol. Lett., 16, 234-241, 2013.

Pausas, J. G.: Response of plant functional types to changes in the fire regime in Mediterranean ecosystems: A simu lation approach, J. Veg. Sci., 10, 717-722, 1999.

Price, P. B. and Sowers, T.: Temperature dependence of metabolic rates for microbial growth, maintenance, and survival, P. Natl. Acad. Sci. USA, 101, 4631-4636, 2004.

Qi, Y. and $\mathrm{Xu}, \mathrm{M}$. .: Separating the effects of moisture and temperature on soil $\mathrm{CO}_{2}$ efflux in a coniferous forest in the Sierra 
Biogeosciences Discuss., https://doi.org/10.5194/bg-2017-345

Manuscript under review for journal Biogeosciences

Discussion started: 21 August 2017

(c) Author(s) 2017. CC BY 4.0 License.

Nevada mountains, Plant Soil, 237, 15-23, 2001.

Raich, J. W. and Potter, C. S.: Global patterns of carbon dioxide emissions from soils, Global Biogeochem. Cy., 9, 23-36, 1995.

Raich, J. W. and Tufekciogul, A.: Vegetation and soil respiration: Correlations and controls, Biogeochemistry, 48, 71-90, 2000 .

Rebmann, C., Kolle, O., Heinesch, B., Queck, R., Ibrom, A., and Aubinet, M.: Data acquisition and flux calcu lations. In: Eddy Covariance: A practical guide to measurement and data analysis, Aubinet, M., Vesala, T., and Papale, D. (Eds.), Springer Science \& Business Media, 79-80 pp., 2012.

Reich, P. B., Sendall, K. M., Stefanski, A., Wei, X., Rich, R. L., and Montgomery, R. A.: Boreal and temperate trees show strong acclimation of respiration to warming, Nature, 531, 633-636, 2016.

Reichstein, M., Rey, A., Freibauer, A., Tenhunen, J., Valentini, R., Banza, J., Casals, P., Cheng, Y., Grünzweig, J. M., Irvine, J., Joffre, R., Law, B. E., Loustau, D., Miglietta, F., Oechel, W., Ourcival, J.-M., Pereira, J. S., Peressotti, A., Ponti, F., Qi, Y., Rambal, S., Rayment, M., Romanya, J., Rossi, F., Tedeschi, V., Tirone, G., Xu, M., and Yakir, D.: Modeling temporal and large-scale spatial variability of soil respiration from soil water availability, temperature and vegetation productivity indices, Global Biogeochem. Cy., 17, 1104, 2003.

Reichstein, M., Tenhunen, J. D., Roupsard, O., Ou rcival, J.-M., Rambal, S., Mig lietta, F., Peressotti, A., Pecchiari, M., Tirone, G., and Valentini, R.: Severe drought effects on ecosystem $\mathrm{CO}_{2}$ and $\mathrm{H} 2 \mathrm{O}$ flu xes at three Mediterranean evergreen sites: revision of current hypotheses?, Global Change Biol., 8, 999-1017, 2002.

Reynolds, L. L., Johnson, B. R., Pfeifer-Meister, L., and Bridgham, S. D.: Soil respiration response to climate change in Pacific Northwest prairies is mediated by a regional Mediterranean climate gradient, Global Change Biol., 21, 487$500,2015$.

Rodhe, H.: A comparis on of the contribution of various gases to the greenhouse effect, Science, 248, $1217,1990$.

Rogers, A. and Humphries, S. W.: A mechanistic evaluation of photosynthetic acclimation at elevated $\mathrm{CO}_{2}$, Global Change Biol., 6, 1005-1011, 2000.

Rustad, L. E., Huntington, T. G., and Boone, R. D.: Controls on soil respiration: Implications for climate change, Biogeochemistry, 48, 1-6, 2000.

Rustad, L., Campbell, J., Marion, G., Norby, R., Mitchell, M., Hartley, A., Cornelissen, J., Gurevitch, J., and Gcte, N.: A meta-analysis of the response of soil respiration, net nitrogen mineralization, and aboveground plant growth to experimental ecosystem warming, Oecologia, 126, 543-562, 2001.

30 Sage, R. F. and Kubien, D. S.: The temperature response of $\mathrm{C}_{3}$ and $\mathrm{C}_{4}$ photosynthesis, Plant Cell Environ., 30, 1086-1106, 
Biogeosciences Discuss., https://doi.org/10.5194/bg-2017-345

Manuscript under review for journal Biogeosciences

Discussion started: 21 August 2017

(c) Author(s) 2017. CC BY 4.0 License.

2007.

Sankaran, M., Hanan, N. P., Scholes, R. J., Ratnam, J., Augustine, D. J., Cade, B. S., Gignou x, J., Higgins, S. I., Le Rou x, X., Ludwig, F., Ardo, J., Banyikwa, F., Bronn, A., Bucini, G., Cay lor, K. K., Coughenour, M. B., Diouf, A., Ekaya, W., Feral, C. J., February, E. C., Frost, P. G. H., Hiernau x, P., Hrabar, H., Metzger, K. L., Prins, H. H. T., Ringrose, S., Sea, W., Tews, J., Worden, J., and Zambatis, N.: Determinants of woody cover in African savannas, Nature, 438, 846-849, 2005.

Saxe, H., Cannell, M. G. R., Johnsen, Ø., Ryan, M. G., and Vourlitis, G.: Tree and forest functioning in response to global warming, New Phytol., 149, 369-399, 2001.

Schaefer, D. A., Feng, W., and Zou, X.: Plant carbon inputs and environmental factors strongly affect soil respiration in a subtropical forest of southwestern China, Soil Biol. Biochem., 41, 1000-1007, 2009.

Scheffer, M. and Carpenter, S. R.: Catastrophic regime shifts in ecosystems: linking theory to observation, Trends Ecol. Evol., 18, 648-656, 2003.

Schipper, L. A., Hobbs, J. K., Rutledge, S., and Arcus, V. L.: Thermodynamic theory explains the temperature optima of soil microbial processes and high $Q_{10}$ values at low temperatures, Global Change Biol., 20, 3578-3586, 2014.

Seneweera, S. P., Ghannoum, O., and Conroy, J.: High vapour pressure deficit and low soil water availability enhance shoot growth responses of a $\mathrm{C}_{4}$ grass (Panicum coloratu m cv. Bambatsi) to $\mathrm{CO}_{2}$ enrichment, Funct. Plant Biol., 25, 287292, 1998.

Song, B., Niu, S., Luo, R., Luo, Y., Chen, J., Yu, G., Olejnik, J., Wohlfahrt, G., Kiely, G., Noormets, A., Montagnani, L., Cescatti, A., Magliulo, V., Law, B. E., Lund, M., Varlagin, A., Raschi, A., Peichl, M., Nilsson, M. B., and Merbold, L.: Divergent apparent temperature sensitivity of terrestrial ecosystem respiration, J. Plant Ecol-UK., 7, 419-428, 2014.

Suding, K. N., Gross, K. L., and Houseman, G. R.: Alternative states and positive feedbacks in restoration ecology, Trends Ecol. Evol., 19, 46-53, 2004.

Swann, A. L. S., Hoffman, F. M., Koven, C. D., and Randerson, J. T.: Plant responses to increasing $\mathrm{CO}_{2}$ reduce estimates of climate impacts on drought severity, P. Natl. Acad. Sci. USA, 113, 10019-10024, 2016.

Tjoelker, M. G., Oleksyn, J., Reich, P. B., and ŻYtkowiak, R.: Coupling of respiration, nitrogen, and sugars underlies convergent temperature acclimation in Pinus banksiana across wide-ranging sites and populations, Global Change Biol., 14, 782-797, 2008.

Wang, W., Smith, J. A., Ramamurthy, P., Baeck, M. L., Bou-Zeid, E., and Scanlon, T. M.: On the correlation of water vapor and $\mathrm{CO}_{2}$ : Application to flu x partitioning of evapotranspiration, Water Resour. Res., 52, 9452-9469, 2016. 
Biogeosciences Discuss., https://doi.org/10.5194/bg-2017-345

Manuscript under review for journal Biogeosciences

Discussion started: 21 August 2017

(c) Author(s) 2017. CC BY 4.0 License.

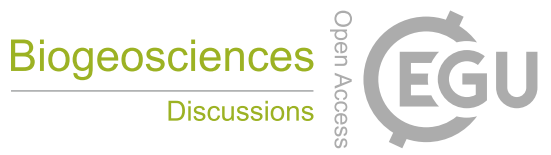

(c) (i)

Wiseman, P. E. and Seiler, J. R.: Soil $\mathrm{CO}_{2}$ efflux across four age classes of plantation loblolly pine (Pinus taeda L.) on the Virginia Pied mont, Forest Ecol. Manag., 192, 297-311, 2004.

Xu, L., and D. D. Baldocchi (2004), Seasonal variation in carbon dioxide exchange over a Mediterranean annual grassland in California, Agr. Forest Meteorol., 123(1-2), 79-96.

$5 \mathrm{Xu}$, L., Baldocchi, D. D., and Tang, J.: How soil mo isture, rain pulses, and growth alter the response of ecos ystem respiration to temperature, Global Biogeochem. Cy., 18, GB4002, 2004.

$\mathrm{Xu}, \mathrm{M}$. and Qi, Y.: Soil-surface $\mathrm{CO}_{2}$ efflux and its spatial and temporal variations in a young ponderosa pine plantation in northern California, Global Change Biol., 7, 667-677, 2001.

Yvon-Durocher, G., Caffrey, J. M., Cescatti, A., Dossena, M., Giorgio, P. d., Gasol, J. M., Montoya, J. M., Pu mpanen, J., Staehr, P. A., Trimmer, M., Woodward, G., and Allen, A. P.: Reconciling the temperature dependence of respiration across timescales and ecosystem types, Nature, 487, 472-476, 2012.

Zheng, Z., Yu, G., Fu, Y., Wang, Y., Sun, X., and Wang, Y.: Temperature sensitivity of soil respiration is affected by prevailing climatic conditions and soil organic carbon content: A trans-China based case study, Soil Biol. Biochem, 41, 1531-1540, 2009.

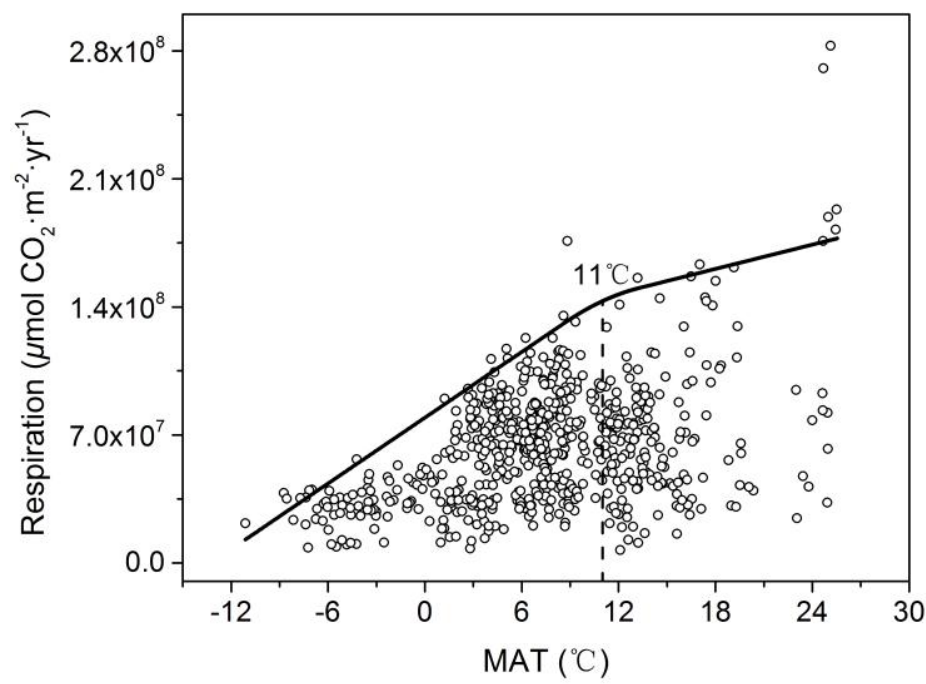

Figure 1: Analy sis of the terrestrial ecosy stem respiration $\left(R_{e}\right)$ rate as a function of mean annual air temperature (MAT) using data of 647 site-years across the globe. The maximum realizable $R_{e}$ rates (i.e., the upper bound of $R_{e}$ ) are represented using the 99th quantile piecewise linear regression. The regression analysis identifies a turning point (i.e., the threshold) at the MAT of $11 \pm 2.3{ }^{\circ} \mathrm{C}$. An equation for the line quantify ing the maximum realizable $R_{e}$ rates in ecosystems with MAT $\leq$ the threshold is $R_{e}=0.19$ (MAT) +2.49 . An equation for the line quantifying the maximum realizable $R_{e}$ rates in ecosy stems with MAT $>$ the threshold is $R_{e}=0.07(\mathrm{MAT})+3.81$. 
Biogeosciences Discuss., https://doi.org/10.5194/bg-2017-345

Manuscript under review for journal Biogeosciences

Discussion started: 21 August 2017

(c) Author(s) 2017. CC BY 4.0 License.

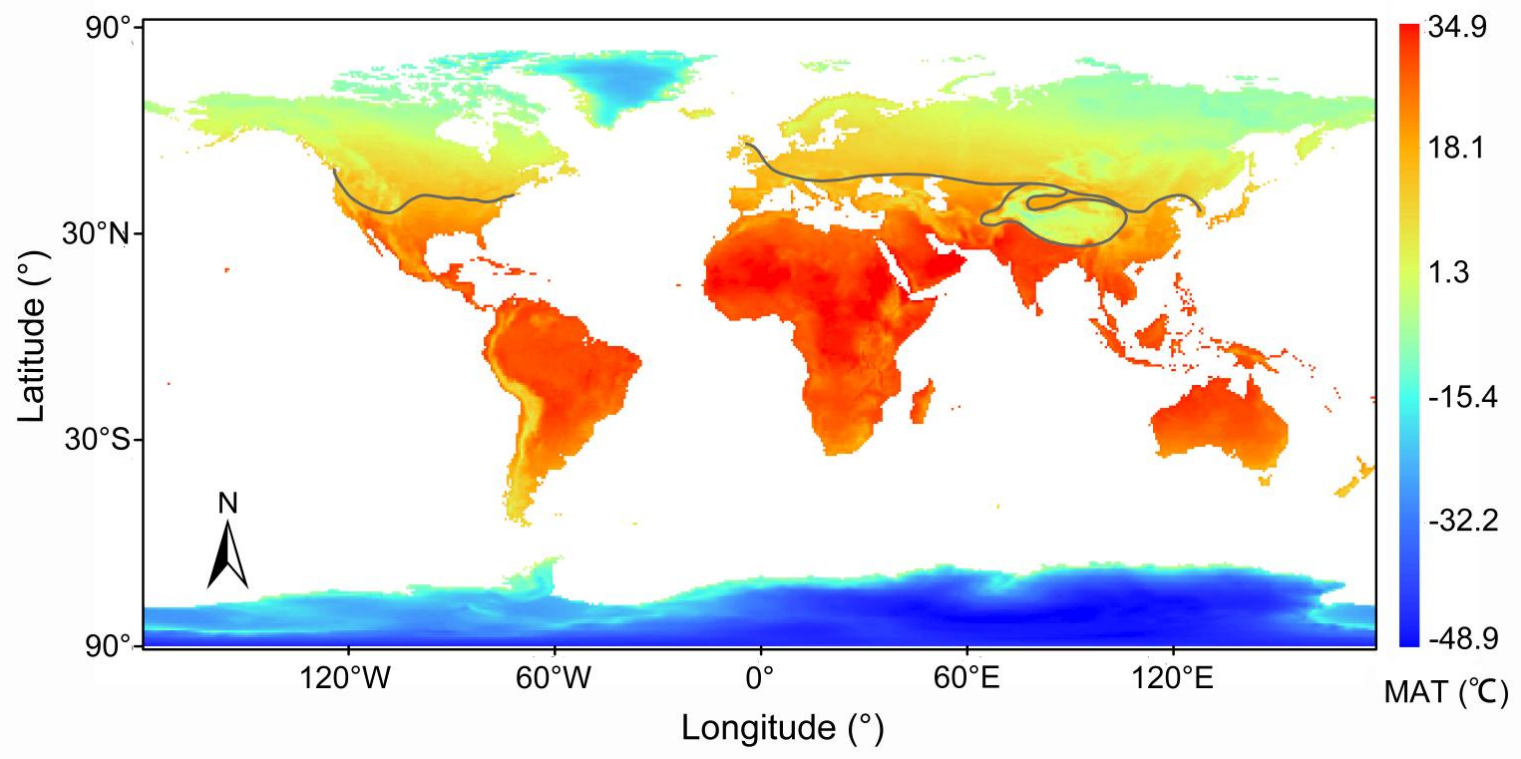

Figure 2: Distributions of patters of terrestrial ecosystem respiration $\left(R_{e}\right)$ rate responses to temperature across the globe. The grey line denotes boundary of the patterns, and the data of MAT were from MERRA (Modern Era Retrospective-Analysis for Research and 5 Application) with 5-year (from 2009-2013) mean values (https://gmao.gsfc.nasa.gov/reanaly sis/MERRA/). 
Biogeosciences Discuss., https://doi.org/10.5194/bg-2017-345

Manuscript under review for journal Biogeosciences

Discussion started: 21 August 2017

(c) Author(s) 2017. CC BY 4.0 License.

\section{(c) (1)}
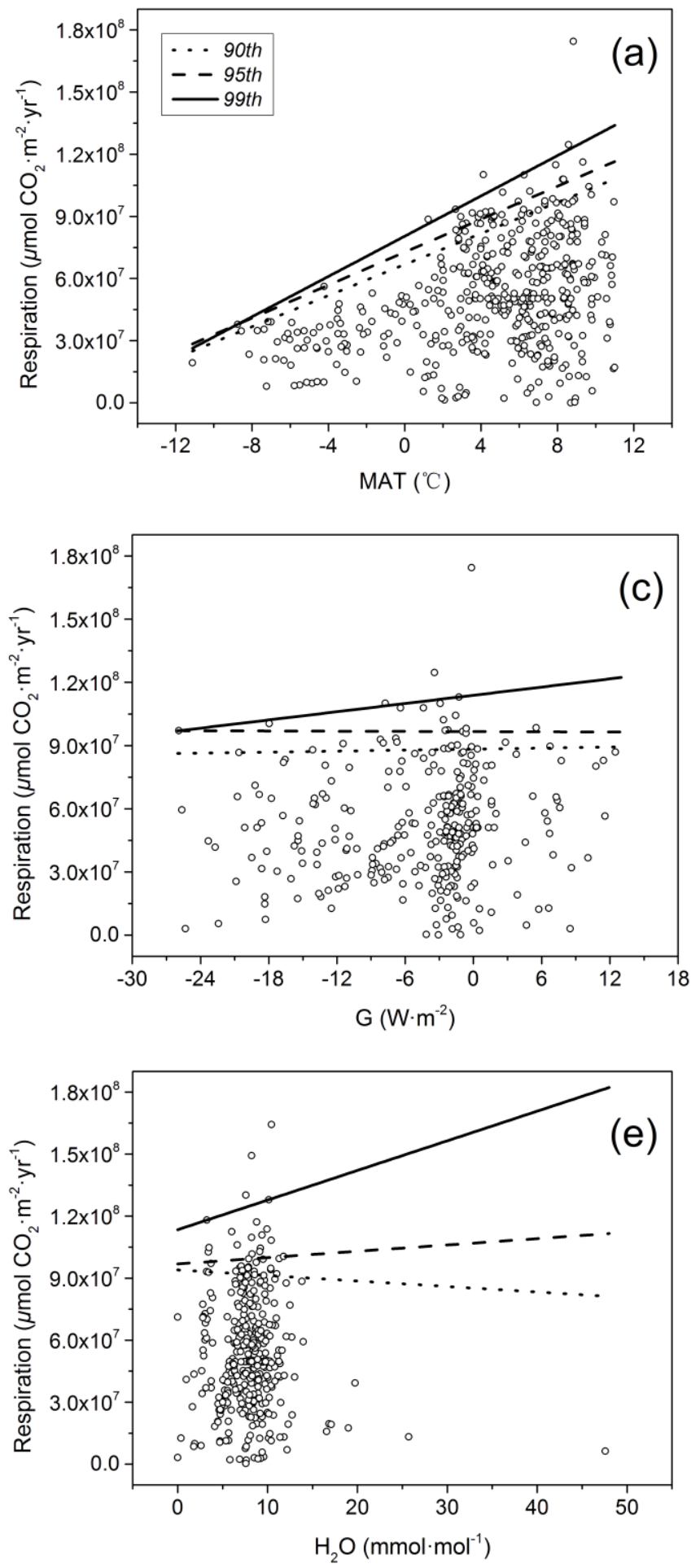

Biogeosciences

Discussions
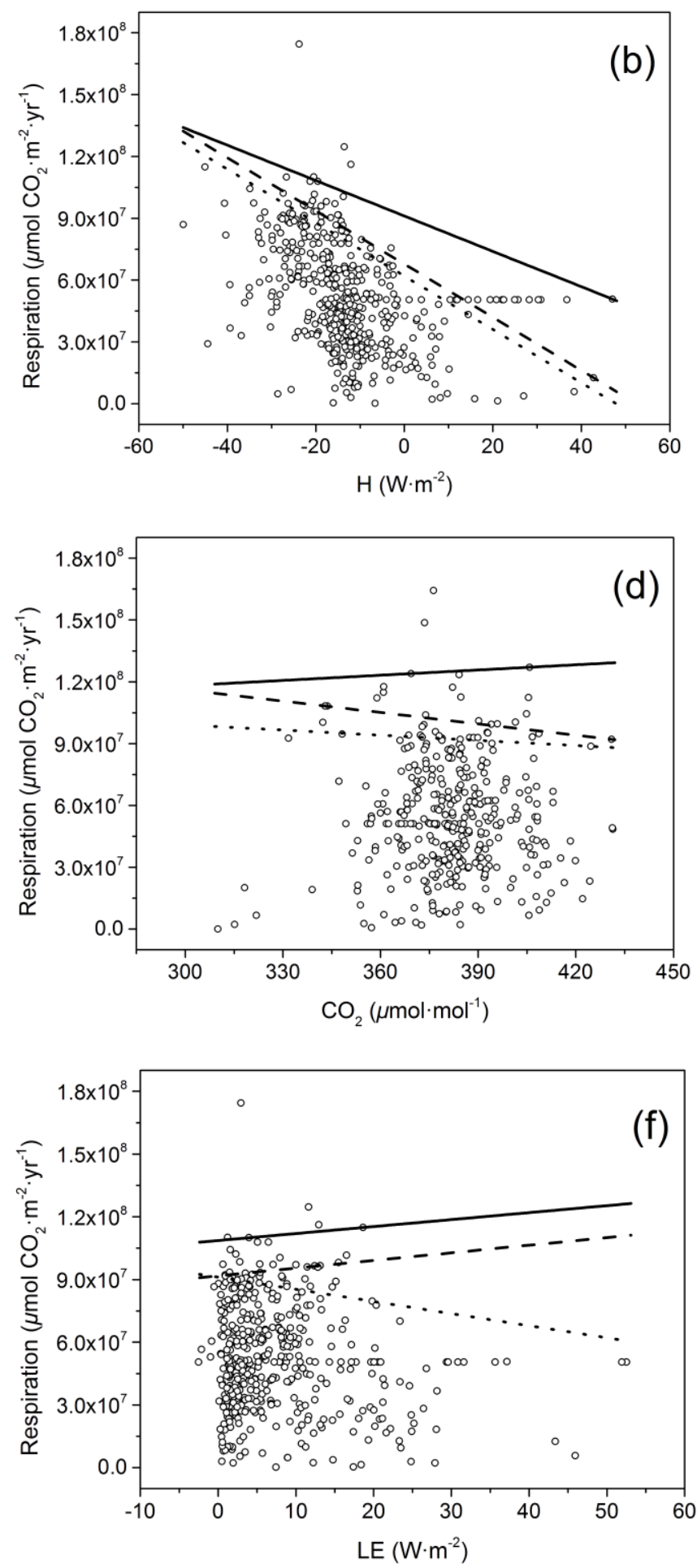
Biogeosciences Discuss., https://doi.org/10.5194/bg-2017-345

Manuscript under review for journal Biogeosciences

Discussion started: 21 August 2017

(c) Author(s) 2017. CC BY 4.0 License.
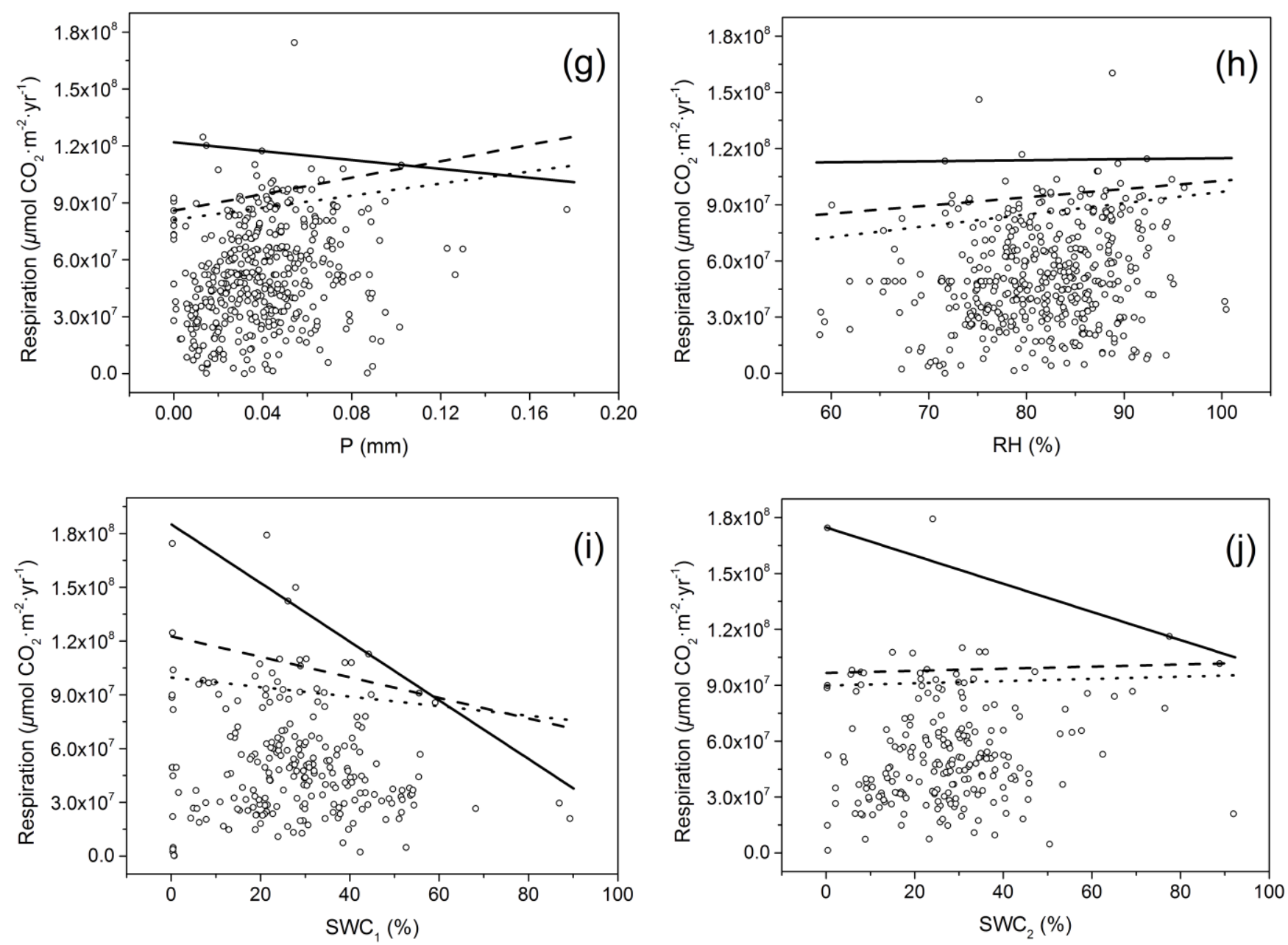

Figure 3: Terrestrial ecosystem respiration $\left(R_{e}\right)$ rates in the terrestrial ecosystems with mean annual air temperature $(\mathrm{MAT}) \leq 11 \pm 2.3^{\circ} \mathrm{C}$ (i.e., in the high-latitude regions) as a function of some micrometeorological factors. Relationships between $R_{e}$ rates and (a) MAT ( $n=$ 456), (b) sensible heat flux $(\mathrm{H})(n=451)$, (c) soil heat flux $(\mathrm{G})(n=311)$, (d) atmospheric $\mathrm{CO}_{2}$ concentration $\left(\mathrm{CO}_{2}\right)(n=374)$, (e) atmospheric $\mathrm{H}_{2} \mathrm{O}$ concentration $\left(\mathrm{H}_{2} \mathrm{O}\right)(n=359)$, (f) latent heat flux (LE) $(n=449)$, (g) precipitation $(\mathrm{P})(n=432)$, (h) relative humidity

5 (RH) $(n=435)$, (i) upper layer soil water content $\left(\mathrm{SWC}_{1}\right)(n=234)$, and $(\mathbf{j})$ lower layer soil water content $\left(\mathrm{SWC}_{2}\right)(n=214)$. Solid, dash, and dot lines represent the $99 \mathrm{th}, 95 \mathrm{th}$, and $90 \mathrm{th}$ linear quantiles, respectively. 
Biogeosciences Discuss., https://doi.org/10.5194/bg-2017-345

Manuscript under review for journal Biogeosciences

Discussion started: 21 August 2017

(c) Author(s) 2017. CC BY 4.0 License.

\section{(c) (1)}
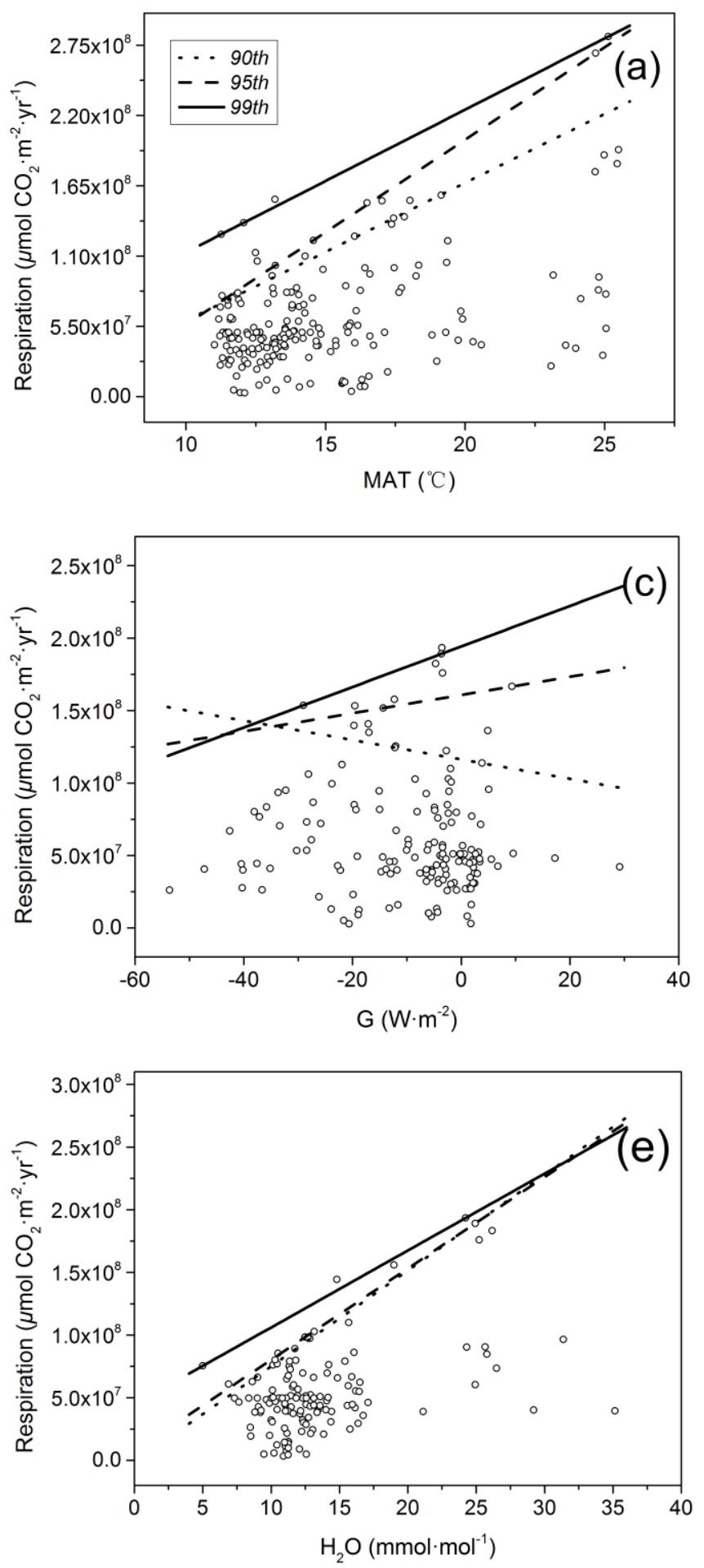
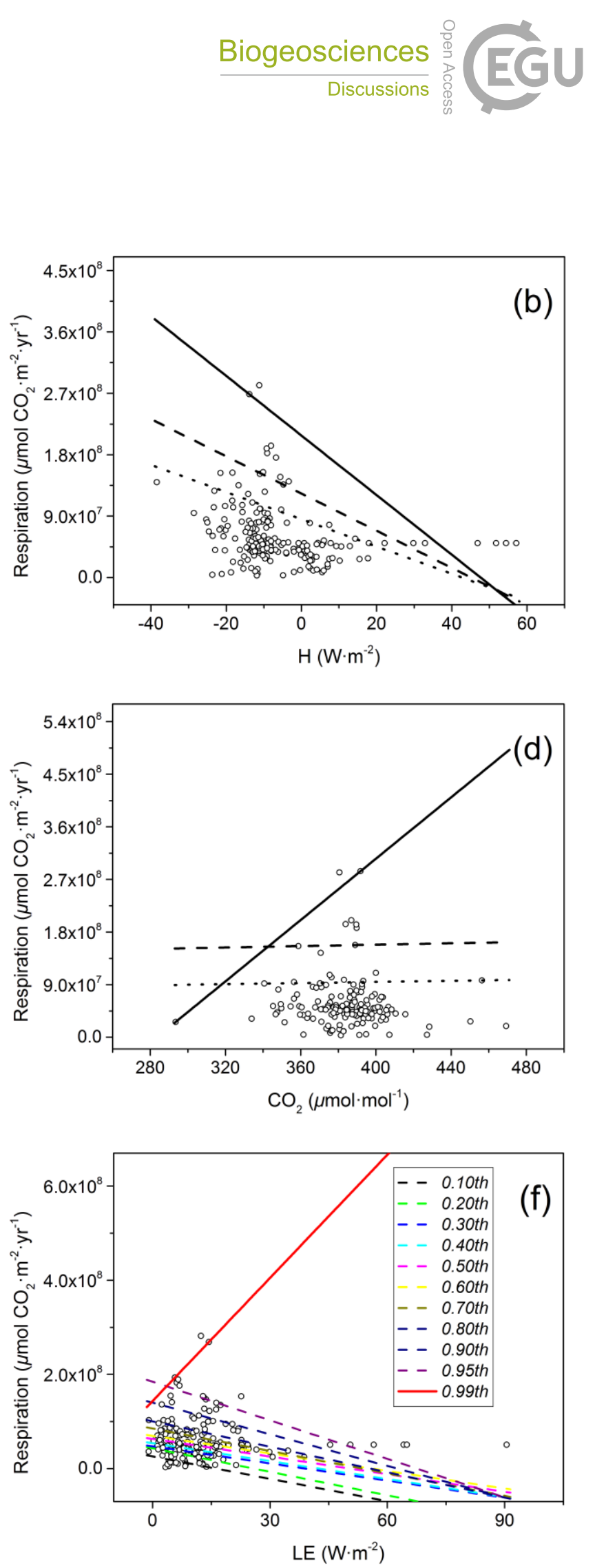
Biogeosciences Discuss., https://doi.org/10.5194/bg-2017-345

Manuscript under review for journal Biogeosciences

Discussion started: 21 August 2017

(c) Author(s) 2017. CC BY 4.0 License.
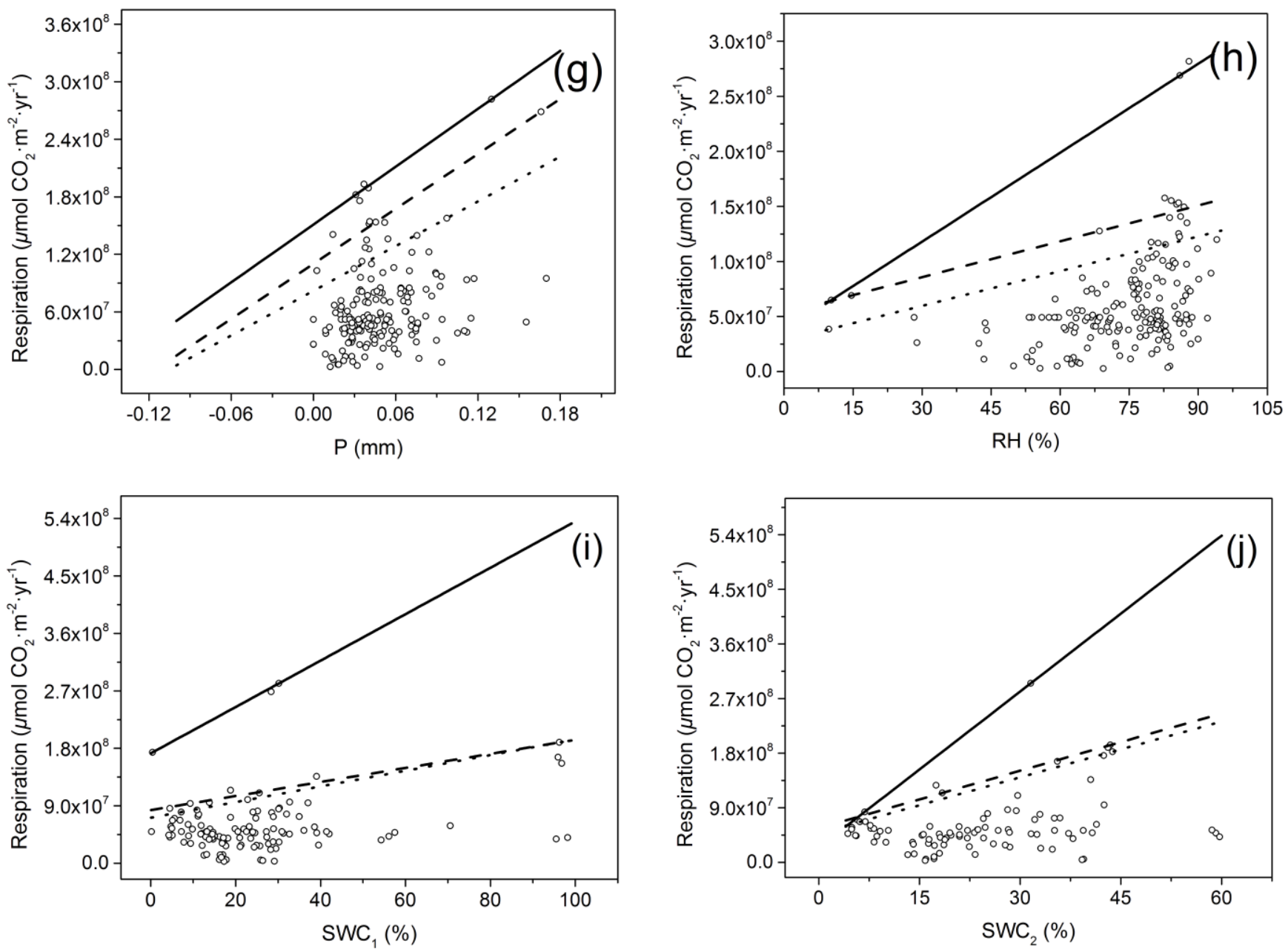

Figure 4: Terrestrial ecosystem respiration $\left(R_{e}\right)$ rates in the terrestrial ecosystems with mean annual air temperature $(\mathrm{MAT})>11 \pm 2.3^{\circ} \mathrm{C}$ (i.e., in lower-latitude regions) as a function of some micrometeorological factors. Relationships between $R_{e}$ rates and (a) MAT ( $\left.n=191\right)$, (b) sensible heat flux $(\mathrm{H})(n=190)$, (c) soil heat flux $(\mathrm{G})(n=159)$, (d) atmospheric $\mathrm{CO}_{2}$ concentration $\left(\mathrm{CO}_{2}\right)(n=156)$, (e) atmospheric $\mathrm{H}_{2} \mathrm{O}$ concentration $\left(\mathrm{H}_{2} \mathrm{O}\right)(n=131)$, (f) latent heat flux (LE) $(n=188)$, (g) precipitation $(\mathrm{P})(n=176)$, (h) relative humidity $(\mathrm{RH})(n=177)$,

5 (i) upper layer soil water content $\left(\mathrm{SWC}_{1}\right)(n=115)$, and (j) lower layer soil water content $\left(\mathrm{SWC}_{2}\right)(n=91)$. Solid, dash, and dot lines represent the 99th, 95th and 90th linear quantiles, respectively. In Fig. 4f, since the trends from the 99th, 95th and 90th linear quantiles were not consistent, the quantile linear regression at $\tau$ levels of 10 th -80 th was conducted to confirm the negative relationship between the maximum realizable $R_{e}$ rates and $\mathrm{LE}$. 
Biogeosciences Discuss., https://doi.org/10.5194/bg-2017-345

Manuscript under review for journal Biogeosciences

Discussion started: 21 August 2017

(c) Author(s) 2017. CC BY 4.0 License.

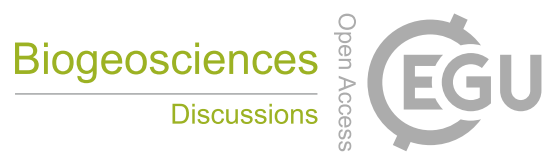

(c) (i)

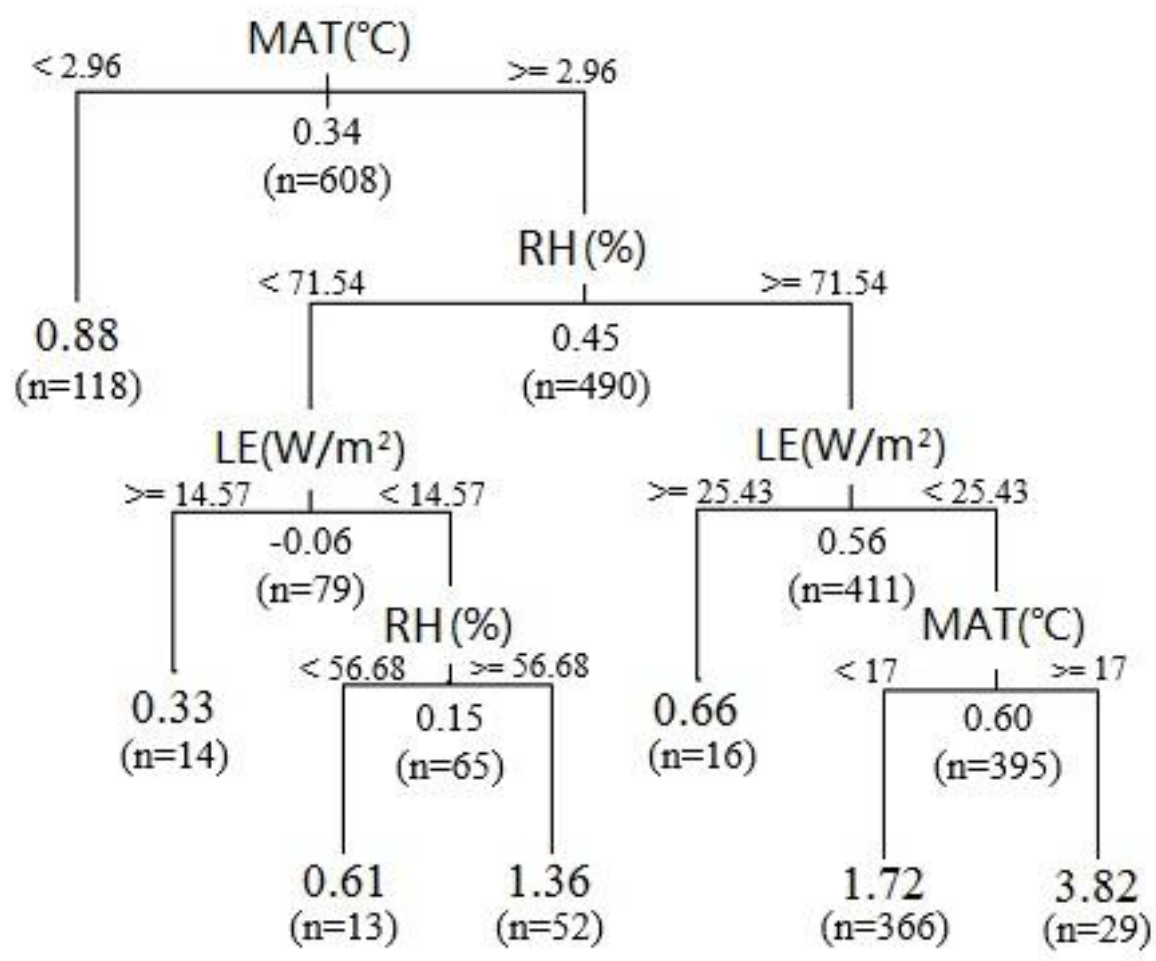

Figure 5: Regression tree showing generalized relationships between the mean $R_{e}$ rates and the micrometeorological factors. The tree is divided into seven terminal nodes. Branches are labeled with criteria used to segregate data. Values in terminal nodes represent mean $R_{e}$ rates of sites grouped within the cluster. 
Biogeosciences Discuss., https://doi.org/10.5194/bg-2017-345

Manuscript under review for journal Biogeosciences

Discussion started: 21 August 2017

(c) Author(s) 2017. CC BY 4.0 License.

(c) (i)

Table 1: $P$ values of the null hypothesis test for quantile regression slopes in 90 th, 95th, and 99th quantiles on mean annual air temperatures (MAT) of terrestrial ecosy stems below $11 \pm 2.3^{\circ} \mathrm{C}$.

\begin{tabular}{ccccccccccc}
\hline Quantile & $\mathrm{MAT}$ & $\mathrm{CO}_{2}$ & $\mathrm{G}$ & $\mathrm{H}$ & $\mathrm{H} 2 \mathrm{O}$ & $\mathrm{LE}$ & $\mathrm{P}$ & $\mathrm{RH}$ & $\mathrm{SWC}_{1}$ & $\mathrm{SWC}_{2}$ \\
\hline 90th & $<0.0001$ & 0.49 & 0.80 & $<0.0001$ & 0.64 & 0.003 & 0.06 & 0.05 & 0.18 & 0.80 \\
95th & $<0.0001$ & 0.25 & 0.98 & $<0.0001$ & 0.73 & 0.03 & $<0.0001$ & 0.22 & 0.15 & 0.73 \\
99th & $<0.0001$ & 0.67 & $<0.0001$ & 0.002 & 0.22 & 0.54 & 0.66 & 0.93 & 0.01 & 0.64
\end{tabular}

MAT is mean annual air temperature. Micrometeorological factors include $\mathrm{CO}_{2}$ : atmospheric $\mathrm{CO}_{2}$ concentration, G: soil heat flux, $\mathrm{H}$ : sensible heat flux, $\mathrm{H}_{2} \mathrm{O}$ : atmospheric $\mathrm{H}_{2} \mathrm{O}$ content, LE: latent heat flux, P: precipitation, $\mathrm{RH}$ : relative humidity, $\mathrm{SWC}_{1}$ : upper layer soil 5 water content, and $\mathrm{SWC}_{2}$ : lower layer soil water content. $P<0.05$ indicates that quantile slope is significantly different from zero.

Table 2: $P$ values of the null hypothesis test for quantile regression slopes in 90th, 95th, and 99th quantiles on mean annual air 10 temperatures (MAT) of terrestrial ecosystems above $11 \pm 2.3^{\circ} \mathrm{C}$.

\begin{tabular}{ccccccccccc}
\hline Quantile & $\mathrm{MAT}$ & $\mathrm{CO}_{2}$ & $\mathrm{G}$ & $\mathrm{H}$ & $\mathrm{H} 2 \mathrm{O}$ & $\mathrm{LE}$ & $\mathrm{P}$ & $\mathrm{RH}$ & $\mathrm{SWC}_{1}$ & $\mathrm{SWC}_{2}$ \\
\hline 90 th & $<0.0001$ & 0.86 & 0.51 & $<0.0001$ & $<0.0001$ & $<0.0001$ & 0.17 & 0.06 & 0.01 & $<0.0001$ \\
95 th & $<0.0001$ & 0.98 & 0.56 & 0.03 & 0.03 & 0.02 & 0.04 & 0.07 & 0.01 & $<0.0001$ \\
99 th & $<0.0001$ & 0.002 & $<0.0001$ & 0.03 & 0.03 & $<0.0001$ & 0.003 & 0.09 & $<0.0001$ & $<0.0001$ \\
\hline
\end{tabular}

